\title{
SKUPINA G20 JAKO NOVÉ FÓRUM PRO KOHERENCI A MULTILATERALIZACI MEZINÁRODNÍHO INVESTIČNÍHO PRÁVA
}

\author{
ONDŘEJ SVOBODA*
}

\begin{abstract}
The Group of G20 as a new forum for coherence and multilateralization of international investment law

The group of G20 has never been previously so much involved in investment policy issues and regulation of investment environment in its short history as of now. The recent Chinese presidency of the group in 2016 nevertheless marked a change by establishment of trade and investment working group whose the most important achievement was the Guiding Principles for Global Investment Policymaking. This brings a question whether the G20 with its global impact and in connection with the recently found interest does not constitute a potential for future comprehensive debates on the system of international investment law and its reform, especially in the context of multilateralization and coherence. This contribution attempts to find an answer through an analysis of current trends in investment policies and the Guiding principles as such.
\end{abstract}

Keywords: G20, investment law, investment policy, guiding principles, multilateralisation

Klíčová slova: G20, investiční právo, investiční politika, rídící principy, multilateralizace

DOI: $10.14712 / 23366478.2017 .30$

Skupina G201 a mezinárodní investiční právo. Dva pojmy, které do nedávna neměly mnoho společného. Členové G20 si však př́i hledání způsobů, jakými oživit globální hospodářský růst, postupně uvědomují, že zahraniční investice jsou pro něj důležitým impulzem a jeho nezbytnou součástí. Zcela nový rozměr aktivního zaměření G20 na problematiku investiční politiky přineslo čínské předsednictví skupině v roce 2016. Č́na v rámci svého předsednictví nejen vytvořila stálou pracovní skupinu G20 pro obchod a investice, ale tato skupina pod jejím vedením připravila během krátké doby i první dokument G20 k investicím pojmenovaný Ř́dicí principy pro tvorbu globálních investičních politik (G20 Guiding Principles for Global Investment Policymaking, dále také jen „Principy“), který byl následně v Šanghaji v červenci 2016 schválen

* Mgr. Bc. Ondřej Svoboda působí jako interní doktorand na katedře mezinárodního práva Právnické fakulty UK a profesně na oddělení mezinárodního práva Ministerstva průmyslu a obchodu ČR. Text byl zpracován v rámci programu Právnické fakulty Univerzity Karlovy Progres Q04 - Právo v měnícím se světě. Jeho obsah je pouze osobním názorem autora a nevyjadřuje oficiální stanovisko MPO ČR. Autor by chtěl poděkovat za cenné postřehy Ing. Mgr. PhDr. Davidu Müllerovi, Ph.D.

1 Skupina G20 sdružuje dvacet nejvýznamnějších světových ekonomik: Jihoafrická republika, Argentina, Brazílie, Kanada, Mexiko, USA, Indonésie, Saudská Arábie, Indie, Čína, Japonsko, Jižní Korea, Rusko, Turecko, Evropská unie, Francie, Německo, Itálie, Spojené království a Austrálie. 
ministry zemí G20 pro obchod a nakonec i na vrcholném summitu představitelů zemí G20 v Chang-čou v záŕí 2016. Obecně platí, že některé jednostranné akty hrají v oblasti mezinárodního práva mezinárodních organizací významnou roli. ${ }^{2}$ Ačkoli G20 není mezinárodní organizací, může hrát tato její iniciativa v rozvoji mezinárodního investičního práva výraznou roli, a to především v multilaterální rovině.

Stávající omezený rozsah multilaterálních investičních pravidel je prìtom v ostrém kontrastu s hustou globální sítí bilaterálních a regionálních dohod. Podle údajů Konference OSN o obchodu a rozvoji (UNCTAD) uzavřely státy za posledních 60 let téměř 3000 dvoustranných dohod o podpoře a ochraně investic (bilateral investment treaties - BITs), ${ }^{3}$ které tvoří spolu s některými regionálními a univerzálními pravidly základ dnešního systému mezinárodního investičního práva. Opravdový multilaterální př́stup však stále chybí. ${ }^{4}$ Tento stav je dán především historickým vývojem, kdy pokusy o multilaterální úpravu investic skončily neúspěchem, at’ už se jednalo o samotný prvopočátek ve formě několika ustanovení k investicím v Havanské chartě v roce 1948, iniciativy na půdě Organizace pro hospodářskou spolupráci a rozvoj (OECD) - návrhy Úmluvy o ochraně zahraničních investic z roku 1962 a Mnohostranné dohody o investicích diskutované v letech 1995-1999, nebo Světové obchodní organizace (WTO), v rámci činnosti Pracovní skupiny pro vztah mezi obchodem a investicemi v období let 1996-2004.

V kontextu těchto neúspěšných snah, kdy selhaly i organizace jevící se jako přirozená místa k debatám nad společnými investičními pravidly jako OECD a WTO, se nyní objevuje G20 jako zcela nové fórum. Při srovnání s předchozími neúspěšnými pokusy však lze pozorovat nejen jistou opatrnost u tradičních hybatelů, za které lze považovat Spojené státy a západoevropské země, nyní členské státy Evropské unie (EU), ${ }^{5}$ ale především podstatnou změnu okolností, které mohou přispět $\mathrm{k}$ dosažení širšího konsenzu, co se týče multilaterální úpravy investic. Zaprvé, se změnou ekonomických sil ve světě se tradiční vývozci investic dostali také do role jejich př́ijemců a naopak rozvojové země, které byly obvykle pouze jejich př́ijemci, se stávají také významnými vývozci. Tento trend je zvláště patrný na příkladu Číny. Zadruhé, aktuálně probíhá několik významných vyjednávání o dvoustranných investičních dohodách a regionálních dohodách o volném obchodu (free trade agreements - FTAs), které podle současných textů obsahují kapitoly upravující liberalizaci investic, jejich ochranu a mechanismus řešení sporů. ${ }^{6}$ Pokud se tyto dohody podaří uzavřít, budou představovat významný krok

2 ŠTURMA, P. - BALAŠ, V.: Ochrana mezinárodnich investic v kontextu obecného mezinárodního práva. Praha, 2012, s. 31.

3 UNCTAD. World Investment Report 2015 - Reforming International Investment Governance. Ženeva, 2015, s. 106.

4 Ačkoli podle Schilla jde spíš o multilaterální systém vytvořený na bázi BITs a prostřednictvím doložek nejvyšších výhod, možností tzv. treaty-shopping a judikatury arbitrážních tribunálů. Bliže viz SCHILL, S. W.: The Multilateralization of International Investment Law. Cambridge, 2009, s. 19-21.

5 Lisabonskou smlouvou pozbyly členské státy EU pravomoci v oblasti př́mých zahraničních investic, které byly přeneseny na unijní úroveň.

6 Máme na mysli především dvě sjednávané BITs mezi EU a Čínou a Spojenými státy a Čínou a tři FTAs: Transatlantické obchodní a investiční partnerství (TTIP) mezi EU a USA, Transpacifické partnerství (TPP) uzavřené 12 tichomořskými zeměmi a Regionální komplexní ekonomické partnerství (RCEP) sdružující východoasijské země, Austrálii a Nový Zéland. 
$\mathrm{k}$ harmonizaci investičních pravidel a mohou vést de facto $\mathrm{k}$ vytvoření jejich společného rámce. ${ }^{7}$ Tento trend nicméně ponecháme dále stranou, protože se v kontextu úvah o novém významu G20 zaměříme především na prvně jmenovaný aspekt.

Při zohlednění výše uvedeného lze souhlasit, že G20 má značný potenciál pro tvorbu investičních pravidel. Její členové jsou největšími vývozci a současně př́ijemci zahraničních investic. Navíc má od počátku minulého roku zcela novou institucionální složku v podobě pracovní skupiny G20 pro obchod a investice. Za těchto okolností se G20 může stát důležitým fórem pro diskuzi a spolupráci nad reformou investičního systému, obzvláště co se týče jeho multilateralizace a zajištění širší koherence. Je ale opravdu reálné očekávat, že především politické uskupení jako skupina G20 může přinést pokrok v natolik kontroverzní oblasti mezinárodního práva? V odpovědi na tuto otázku se příspěvek nejdříve soustředí na analýzu nových trendů v investičních tocích, v uzavírání investičních dohod a v souvisejících investičních sporech. Uvedené změny mají vliv na ofenzivní a defenzivní postoje vyspělých i rozvojových zemí, které zaujímají k regulaci zahraničních investic. Zvláštní důraz bude přitom kladen na Čínu jako zemi, která je ukázkovým prríkladem tohoto procesu. To potvrdila $\mathrm{v}$ rámci předsednictví $\mathrm{G} 20 \mathrm{v}$ roce 2016, jehož průběh a výstupy budou následně popsány a zhodnoceny. Pozornost bude zvláště věnována rozboru Principů, at' už pohledu jejich širšího významu nebo obsahu. V závěru je při zohlednění zjištěných poznatků nová iniciativa G20 stejně jako samotné Principy přijaty pozitivně. Rozhodujícím momentem pro rozvoj činnosti G20 v oblasti investiční politiky však zůstane politický zájem se tímto tématem dále zabývat.

\section{PROMĚNY GLOBÁLNÍHO INVESTIČNÍHO PROSTŘEDÍ}

V dř́ivějších vyjednáváních, at’ už na půdě OECD nebo WTO, byl vždy patrný rozdíl mezi pozicemi zemí vyvážejícími kapitál a zeměmi, které jej přijímají. Pro období 60. a 70. let byl nejdř́ive typický konflikt mezi vyspělými rozvinutými zeměmi na straně jedné a rozvojovými a socialistickými státy na straně druhé. Znatelný rozdíl mezi pozicemi zemí, které investice vyvážely, a zeměmi, které sloužily jako hostitelské země pro tyto investice, hrál později zásadní roli při neúspěchu vyjednávání o Mnohostranné dohodě o investicích i pozdějších diskuzích ve WTO v 90 . letech a později. Tato dělící linie převážně odrážela tradiční rozdělení na vyspělé a rozvojové země a odlišné př́stupy k zacházení se zahraničními investicemi zůstávají relevantní dodnes. Situace se nicméně postupně mění. Investice mírí oběma směry, a zatímco investice z vyspělých zemí v posledních letech spíše stagnovaly, u rozvojových zemí vzrostly mezi rokem 2014 a 2015 o $23 \%$. Z rozvojových zemí tak v roce 2015 pocházela více než jedna třetina všech přímých zahraničních investic, přičemž v roce 2000 to byla pouhá desetina. ${ }^{8}$

7 SAUVANT, K. P.: China, the G20 and the International Investment Regime. China World Economy, sv. 24, č. 4/2016, s. 78-79; FELDMAN, M. - VIGNOLO, R. M. - CHIFFELLE, C. R.: The Role of Paific Rim FTAs in the Harmonisation of International Investment Law: Towards a Free Trade Area of the AsiaPacific. International Centre for Trade and Sustainable Development, 2016, s. 2.

8 UNCTAD, Report, s. 30-31. 
V dnešní době tak rozvojové země nezohledňují ve svých politikách čistě defenzivní zájmy. Jako země vyvážející investice chtějí také ony chránit své investory v zahraničí a usnadňovat jim vstup na jiné trhy. Přirozeně jejich investoři začínají využívat i ochrany poskytované BITs a přibývá investičních sporů, které zahájili investoři ze zemí, které nepatří mezi tradiční vývozce kapitálu. Veřejně známé jsou např. čtyři spory zahájené čínskými investory, tři indickými a jihokorejskými investory a po jednom investičním sporu již vedli investoři jihoafričtí, saudskoarabští, mexičtí a argentinští. U tureckých investorů se dokonce eviduje 19 sporů. ${ }^{9}$ Naopak vyspělé země, donedávna hlavní vývozci kapitálu, čelí rostoucímu počtu žalob ze strany zahraničních investorů, ${ }^{10}$ což je nově vede $v$ jejich smluvní praxi $k$ tomu, aby více dbaly o defenzivní zájmy. Dříve platilo, že z těchto zemí pocházela většina významných investorů a měly určující vliv na mezinárodní standardy pro zacházení s investicemi. Proto tyto standardy upřednostňovaly především zájmy investorů. Nově jsou však rozvinuté země nuceny reagovat na situace, kdy jsou sami hostitelskými zeměmi pro investice ze zahraničí a čelí následným, často kontroverzním, sporům. To způsobuje u jejich občanů stále častější pochybnosti a obavy nad stávajícím investičním systémem. ${ }^{11}$

Dalším důležitým trendem je uzavírání BITs mezi rozvojovými státy a jejich výraznější role při tvorbě mezinárodních investičních pravidel. ${ }^{12}$ Dvoustranné ani regionální dohody se již dlouho neuzavírají pouze mezi vyspělými zeměmi na jedné straně a rozvojovými zeměmi na straně druhé. Přibližně $40 \%$ všech BITs uzavřely rozvojové země mezi sebou. ${ }^{13}$ Aktivní jsou především v uzavírání regionálních dohod, z nichž mnohé obsahují závazky k liberalizaci či ochraně investic. ${ }^{14}$ Rostoucí vliv je typický především pro asijské země. Tento vývoj je logickým důsledkem změn v globálních investičních tocích, kdy se Asie stala v rámci regionů hlavním zdrojem zahraničních investic. ${ }^{15}$ Tamní země se tak logicky snaží více prosazovat $\mathrm{v}$ debatách na různých mezinárodních úrovních nad podobou pravidel regulujících zahraniční investice a systém investičního práva se zapojením nových aktérů navíc stává reprezentativnějším. ${ }^{16}$

Tato nová krajina globálního investičního prostředí tak směřuje k postupné konvergenci zájmů obou skupin zemí, což by mělo napomoci dosažení kompromisu nad

9 Seznam sporů a podrobnosti k nim lze nalézt na UNCTAD Investment Dispute Settlement Navigator [online]. 12. 10. 2016. Dostupné na <http://investmentpolicyhub.unctad.org/ISDS>.

10 V roce 2014 bylo celých $40 \%$ sporů zahájených proti rozvinutým státům a např. Itálie čelila žalobě ze strany zahraničního investora poprvé $\mathrm{v}$ historii.

11 Nejvýrazněji se odpor proti investiční ochraně a zvláště systému řešení sporů investor-stát projevil ve veřejné konzultaci, kterou zahájila Evropská komise $\mathrm{k}$ investiční kapitole pro TTIP a následném novém př́stupu EU k ochraně investic.

12 Rostoucí vliv rozvojových zemí není omezen pouze na oblast investic, ale také na obchodní pravidla a agendu WTO. Viz např. DRAHOS, P.: When the Weak Bargain with the Strong: Negotiations in the World Trade Organization. International Negotiation, sv. 8, č. 1/2003; HOPEWELL, K.: Different path to power: The rise of Brazil, India and China at the World Trade Organisation. Review of International Political Economy, sv. 22, č. 2/2015.

13 POULSEN, L. S.: The Significance of South-South BITs For the International Investment Regime: A Quantitative Analysis. Northwestern Journal of International Law \& Business, sv. 30, č. 1/2010, s. 101.

14 DATTU, R.: A Journey from Havana to Paris: The Fifty-Year Quest for the Elusive Mutilateral Agreement on Investment. Fordham International Law Journal, sv. 24, č. 1/2000, s. 277.

15 UNCTAD, Report, s. 5.

16 SCHILL, S. W.: Changing geography: prospects for Asian actors as global rule-makers in international investment law. Columbia FDI Perspectives, č. 177/2016, s. 2. 
univerzálními pravidly pro investice, at' už v omezené podobě, nebo ve formě multilaterální dohody. ${ }^{17}$

Čína jako výrazný hybatel v současných debatách o tvorbě pravidel regulujících toky zahraničních investic je dokonalým ilustrativním př́kladem. Na tomto poli je z rozvojových zemí jednoznačně nejaktivnější, jak ostatně potvrdila během předsednictví G20. Její zájem odpovídajícím způsobem odráží vzrůstající čínské investice v zahraničí a rozvoj vlastní investiční politiky. Čínské vnější přímé zahraniční investice dlouhodobě rostou a tento trend bude pravděpodobně nadále pokračovat, zvláště v odvětvích služeb a infrastruktury. ${ }^{18} \mathrm{Z}$ poslední doby jsou dobře známé velké čínské investiční plány, at' už se jedná o založení Asijské investiční banky pro infrastrukturu nebo projekt Nové hedvábné stezky. Čínské společnosti nicméně současně čelí v zahraničí rostoucím překážkám. Tato situace je téměř imperativem pro čínskou vládu, aby zlepšila ochranu a př́stup čínských investorů na bilaterální, regionální i multilaterální úrovni. ${ }^{19}$ Čína má v současnosti uzavřeno na 148 dohod týkajících se úpravy zahraničních investic, z nichž je 129 bilaterálních a 19 jiného typu. ${ }^{20}$ Ačkoliv Čína nemá vyvinutou vlastní vzorovou investiční dohodu, lze v její smluvní praxi vystopovat několik „generací“ investičních modelů, přičemž poslední vývoj se vyznačuje rostoucím důrazem na ochranu zájmů čínských investorů a zlepšení podmínek pro jejich operace. ${ }^{21}$ Pro názornou ukázku nových rolí jednotlivých zemí a regionů $\mathrm{v}$ kontextu čínského př́ikladu poslouží dvě skutečnosti. První z nich je údaj, že téměř $60 \%$ čínských investic směřovalo do vyspělých zemí jako Austrálie, Spojené státy, Německo a Kanada. ${ }^{22}$ Druhým př́kladem je investiční spor, kdy čínští investoři zažalovali Belgii poté, co během finanční krize v roce 2008 vykoupila a následně znárodnila a prodala třetí straně finanční instituci, do které čínské společnosti investovaly. ${ }^{23}$

V těchto podmínkách má G20, tvořená dvaceti největšími ekonomikami světa, přesněji 19 zeměmi a EU, ambice formulovat hlavní rámec pro hospodářskou spolupráci a může hrát unikátní roli mostu mezi tradičními hospodářskými velmocemi, de facto zeměmi skupiny $\mathrm{G} 7$, a rostoucími ekonomikami v čele s Čínou. Jde o poměrně nový formát mezinárodní spolupráce původně založené jako pravidelné roční zasedání ministrů financí a guvernérů centrálních bank v reakci na světovou finanční krizi v letech 1997-1999. Původně byla G20 založena jako nový mechanismus pro neformální dialog, za účelem budování konsenzu nad mezinárodními otázkami a se zvláštním zaměřením na mezinárodní finanční stabilitu. Postupně se agenda uskupení rozšiřuje, protože

17 SAUVANT, c. d., s. 78.

18 UNCTAD, Report, s. 41.

19 HE, F. - BIJUN W.: Chinese interests in the global investment régime. China Economic Journal, sv. 17, č. $1 / 2004$, s. 18 .

20 UNCTAD International Investment Agreements Navigator [online]. 12. 10. 2016. Dostupné na <http:// investmentpolicyhub.unctad.org/IIA>.

21 Pro podrobnější popis vývoje čínské smluvní praxe viz např.: BERGER, A.: Hesitant Embrace: China's Recent Approach to International Invesment Rule-Making. Journal of World Investment \& Trade, Sv. 16 , č. 5-6/2015.

22 BIJUN, W.: A Misread Official Data: The True Pattern of Chinese ODI. International Economic Review, č. 1/2013, s. 61-74.

23 Ping An Life Insurance Company of China, Limited and Ping An Insurance (Group) Company of China, Limited v. Kingdom of Belgium, ICSID Case No. ARB/12/29. 
s členskými ekonomikami, které přestavují přibližně $85 \%$ celosvětového HDP, se jedná o formát spolupráce s velkým potenciálem. Prozatím však G20 byla spíše terčem kritiky pro svůj malý praktický dopad na globální ekonomiku. Je však zapotřebí mít realistická očekávání v tom, co lze spoluprací na globální úrovni dosáhnout. ${ }^{24}$

To platí i co se týče investic. Statistiky dokládají, že podíl zemí G20 jako vývozců zahraničních investic zahrnuje od roku 2007 stabilně přes $60 \%$ veškerých investičních toků. ${ }^{25}$ Téměř ve stejném podílu byly také jejich recipienty. ${ }^{26} \mathrm{O}$ potenciálu skupiny svědčí i další údaje. V úvodu bylo řečeno, že je evidováno na 3000 investičních dohod. U celých $40 \%$, přesně 1175 , je jednou smluvní stranou země G20. Pokud jde o jiné mezinárodní dohody upravující investiční toky, např. FTAs, je toto číslo ještě větší, a to $77 \%$. Podobně zajímavé statistiky se týkají i investičních sporů. V celkem 381 př́padech, tj. $57 \%$ všech známých sporů, byla žaloba podána investorem ze země G20. Země G20 byly žalovány ve 183 sporech, což činí $27 \%$ podíl. G20 tak má nepochybně pro svoji různorodost a váhu potenciál stát se mimořádně prospěšným diskuzním forem s významným vlivem na tvorbu a na vývoj investičních politik.

Tento potenciál, kdy se investicím na agendě G20 dostává zvýšené pozornosti, se začíná v posledních dvou letech pomalu naplňovat. Poprvé se to projevilo v závěrečném komuniké představitelů G20 na jejich setkání v Antalyi v Turecku v listopadu 2015. V tomto dokumentu se mj. zavázali k posílení investic a konkrétním krokům za účelem zlepšení investičního prostředí, které by dle odhadu OECD mohly vést k nárůstu poměru celkových investic G20 vůči HDP do roku 2018 o jedno procento. ${ }^{27}$ Představitelé G20 dále potvrdili, že světový obchod a investice jsou a budou důležitými motory hospodářského růstu a rozvoje, které vytvářejí pracovní místa a přispívají obecnému prospěchu. ${ }^{28}$ Nejnověji se představitelé G20 na summitu v Chang-čou v záŕí 2016 zavázali $\mathrm{k}$ usnadňování (facilitaci) a liberalizaci investic. ${ }^{29}$ Ačkoliv se to může jevit jako banální, nenahlížely vždy některé méně vyspělé země, které jsou členy G20, na obchod a investice pozitivně. S ohledem na omezený růst obchodu i investic dále nejvyšší představitelé G20 předestřeli širší spolupráci, a to zvláště v boji proti protekcionistickým opatřením. S tímto cílem se také měli pravidelně setkávat ministři obchodu a měla být vytvořena specializovaná pracovní skupina. ${ }^{30}$

\section{ČÍNSKÉ PŘEDSEDNICTVÍ SKUPINY G20}

Na závěry antalijského summitu navázalo následné čínské předsednictví v uplynulém roce. V dokumentu oznamujícím hlavní programové body svého před-

24 AMIGHINI, A. - GOLDSTEIN, A.: Introduction: Contextualizing the 2016 G20: Global Analyses and Challenges for the Chinese Presidency. China \& World Economy, sv. 24, č. 4/2016, s. 1-2.

25 UNCTAD G20 Investment Fact Sheet [online]. 12. 10. 2016. Dostupné na $<$ http://investmentpolicyhub .unctad.org/Upload/Documents/G20_factsheet_FINAL.pdf >.

26 Ibid.

27 G20 Leaders' Communiqué, 16. 11. 2015, odst. 9.

28 Ibid, odst. 11.

29 G20 Leaders' Communique Hangzhou Summit, 5. 9. 2016, odst. 25.

30 Ibid. 
sednictví skupiny G20 v roce 2016 zaujímají investice prominentní místo a opětovně je uznána jejich klíčová role pro hospodářský růst. $\mathrm{V}$ dokumentu je dále konstatováno, že celosvětově narůstá počet obchodních a investičních dohod a ačkoliv země G20 podporují liberalizaci a posilování obchodu a investic, vede to také $\mathrm{k}$ fragmentaci jejich úpravy, na což musí G20 reagovat. ${ }^{31}$ G20 by tak měla prozkoumat možnosti vytvoření nezávazných investičních principů při zohledňování problémů, kterým musí čelit rozvojové země. Současně by G20 měla sloužit jako platforma rozvoje spolupráce v oblastech jako sdílení osvědčených postupů, výměna informací či vytváření vhodného politického prostředí. ${ }^{32}$ Podle očekávání se tedy investice staly jedním z prioritních témat a Čína byla $\mathrm{v}$ této oblasti značně ambiciózní.

Potvrzením skutečného zájmu Číny o mezinárodní investice bylo založení pracovní skupiny G20 pro obchod a investice hned na začátku jejího předsednictví. Nejen že skupina představuje vhodný formát $\mathrm{k}$ výměně názorů a hledání konsenzu u mnoha investičních témat pro zástupce a národní experty zemí G20, ale je také příležitostí k posílení koherence mezi obchodem a investicemi, což je vztah, který je někdy opomíjený. Pracovní skupina se setkala celkem čtyřikrát - v lednu v Pekingu, v dubnu v Nankigu, neoficiálně na přelomu května a června v Paříži a v červenci v Šanghaji. Jednotlivých zasedání se vedle delegátů zemí G20 navíc účastnili také zástupci jiných států a mezinárodních organizací, aby do diskuzí přispěli svojí expertízou. Na prvním setkání si předsednická země vytyčila pro pracovní skupinu tři cíle: posílit spolupráci G20 v obchodu a investicích a podporovat setkávání ministrů obchodu $\mathrm{G} 20$; přispět k multilaterálnímu obchodnímu systému a konečně napomoci silnému oživení světového obchodu a investic a zahájení spolupráce např. při formulování globálního investičního rámce. ${ }^{33} \mathrm{Na}$ druhém setkání se již debata zaměřila na několik konkrétních témat, mezi kterými se objevily nezávazné principy investičních politik, usnadňování investic, posílení podpory nízkopříjmových zemí a užší koordinace obchodních a investičních politik. ${ }^{34}$ Poslední setkání pak především připravilo půdu pro historicky první jednání ministrů obchodu G20. ${ }^{35} \mathrm{O}$ samotném průběhu všech jednání a jejich agendě bohužel nejsou dostupné další bližší informace.

Výstupy červencového zasedání ministrů obchodu G20 ve formě ministerské deklarace s třemi př́lohami (Zásady činnosti pracovní skupiny G20 pro obchod a investice, Strategie G20 pro růst světového obchodu a Řídící principy pro tvorbu globálních investičních politik $)^{36}$ jsou zajímavé hned v několika ohledech. Ministři přivítali vytvoření pracovní skupiny G20 pro obchod a investice a odsouhlasili zásady její činnosti uvedené

31 China's G20 2016 priorities document and statement by Xi Jingpin, President of the People's Republic of China, 1. 12. 2015, s. 9-10.

32 Ibid, s. 12.

33 First G20 Trade and Investment Working Group Meeting Held. In Ministry of Commerce People's Republic of China [online]. 8. 11. 2016. Dostupné na <http://english.mofcom.gov.cn/article/newsrelease /significantnews/201602/20160201251500.shtml>.

34 2nd Meeting of the G20 Trade Investment Working Group Held in Nanjing. In Ministry of Commerce People's Republic of China [online]. 8. 11. 2016. Dostupné na <http://english.mofcom.gov.cn/article /newsrelease/significantnews/201604/20160401291087.shtml>.

35 The 3rd Meeting of the G20 Trade and Investment Working Group Held in Shanghai. In Ministry of Commerce People's Republic of China [online]. 8. 11. 2016. Dostupné na $<$ http://english.mofcom.gov.cn /article/newsrelease/significantnews/201607/20160701358736.shtml>.

36 V̌̌echny uvedené dokumenty dostupné na <http://www.g20.utoronto.ca/2016/160905-annex.html>. 
v př́loze I. ${ }^{37} \mathrm{Z}$ toho lze usoudit, že pracovní skupina se nyní stane stálou součástí struktury G20 stejně jako obchodní a investiční témata zůstanou v dohledné době v agendě G20. Tento krok lze hodnotit jednoznačně pozitivně. Do činnosti pracovní skupiny se zapojili zástupci zemí G20 spolu s experty mezinárodních organizací a připravili během sedmi měsíců společné prohlášení pro ministry obchodu s třemi přiloženými dokumenty, což je jistě úspěch s ohledem na to, jak je obtížné dosahovat konsenzu v obchodních a zvláště investičních otázkách. Tyto výstupy jsou také důkazem potenciálu, který pracovní skupina má jako institucionalizovaná spolupráce pro hledání širší shody mezi rozvinutými a rozvojovými ekonomikami ohledně investičních politik. V ministerské deklaraci je také zmínka o usnadňování investic, přičemž UNCTAD, Světová banka, OECD a WTO jsou v rámci svých mandátů vyzvány $\mathrm{k}$ pokračující práci v této oblasti pro budoucí využití jejich aktivit ze strany G20. ${ }^{38} \mathrm{Na}$ základě toho lze předjímat, že se toto téma na úroveň $\mathrm{G} 20$ vrátí a bude diskutováno. Při závěrečném zhodnocení výstupů čínského předsednictví se tak ukázalo, že se v oblasti investic podařilo $\mathrm{v}$ omezeném časovém prostoru dokončit pouze jednu z původně deklarovaných iniciativ, kdy jediným konkrétním výstupem jsou nakonec Principy tvořící př́lohu III deklarace.

\section{VÝZNAM A SLABINY PRINCIPŮ PRO TVORBU GLOBÁLNÍCH INVESTIČNÍCH POLITIK}

Principy se skládají z devíti obecných zásad s relativně vyrovnaným obsahem, který se snaží uspokojit zájmy všech zemí G20 a jejich vyjednavačů. Ve stručnosti představují tyto východiska: 1 . boj proti protekcionismu, 2. zajištění nediskriminace, 3. investiční ochrana, 4. transparentní tvorba politik, 5. udržitelný a inkluzivní růst, 6. uznání práva na regulaci, 7. podpora a usnadňování investic, 8. dodržování osvědčených postupů u společenské odpovědnosti podniků a správy společností a 9. pokračování dialogu k mezinárodním investicím. Popsané zásady by měly dle jejich tvůrců napomoci větší koherenci na úrovni národních i mezinárodních investičních politik, a tím přispět k otevřenějšímu, transparentnějšímu a předvídatelnějšímu investičnímu prostředí. ${ }^{39}$

Při bližším pohledu není na Principech možná natolik zajímavý jejich obsah, ale skutečnost, že představují výsledek shody a společného úsilí zemí, které zaujímají v oblasti investic značně odlišné postoje, pokud uvážíme, jaké země jsou členy G20. Je to snad poprvé, co byl u investičních politik dosažen konsenzus mezi tak různorodou skupinou zemí, která ale současně představuje dvě třetiny celosvětových př́mých zahraničních investic. Je však vhodné připomenout, že shoda nad některými body byla dosažena již dřive, ovšem v odlišných formátech. V roce 2009 se v rámci heiligendammského dialogu shodly země skupiny G8 (Německo, Spojené státy, Velká Británie, Francie, Itálie, Japonsko, Kanada, Rusko) a skupiny G5 (Brazílie, Čína, Mexiko, Indie, Jižní Afrika) mj. na ,podpoře, ochraně a usnadňování mezinárodních investic s cílem posílení hospodářského a společenského rozvoje. Je zde zjevná potřeba posílit otevřené a transparentní

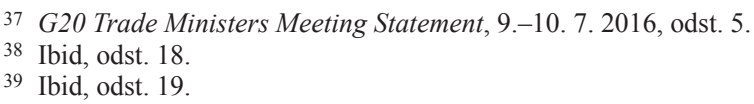


investiční režimy a potlačit snahy o vytváření překážek a omezení. Současně je třeba uznat, že každá země má především svoji odpovědnost za vlastní hospodářský a společenský rozvoj a za ochranu vlastních legitimních národních bezpečnostních zájmů."40 Dalším př́kladem je Prohlášení ke sdíleným principům pro mezinárodní investice, které společně prezentovaly Evropská unie a Spojené státy v roce 2012 a představovaly jednotnou pozici těchto tradičních zemí vyvážejících kapitál k budoucímu směřování investičních standardů. ${ }^{41}$ Pro úplnost ještě dodejme Nezávazné investiční principy Ekonomického seskupení Asie a Tichomoří (APEC) v revidované verzi z roku 2011, kde lze nalézt mnoho společných bodů s výše uvedenými dokumenty. ${ }^{42}$

Principy schválené G20 však mají v porovnání s ostatními dokumenty větší váhu. Mohou totiž posloužit jako základ k další spolupráci členských zemí G20 v investiční politice. Ačkoli deklarované standardy jsou obecného rázu, platí, že odráží jistou míru shody nad dalším směřováním u skupiny zemí, které se podílely na jejich formulování. Identita tvưrců, v tomto prŕípadě dvaceti nejvýznamnějších světových ekonomik, právně nezávazných dokumentů (soft law) je zásadním předpokladem pro jejich přijetí. ${ }^{43}$ Podle některých názorů jsou tak tyto Principy prvním krokem k debatě o podobě mnohostranné investiční dohody. ${ }^{44}$ Ta by rovněž mohla obsahovat nejen tradiční investiční ochranu a systém řešení sporů, ale upravovala by rovněž společenskou odpovědnost podniků a problematiku státem vlastněných společností. ${ }^{45}$ Důležitost Principů vyzdvihly i mezinárodní organizace, které na jednáních pracovní skupiny účastnily. Dle vyjádření představitelky OECD jsou Principy ,předkrmem“, který může vytyčit cestu vpred, pokud bude u členů G20 politická vůle k dalším reformám. ${ }^{46}$ Generální tajemník UNCTAD dokonce Principy označil za klíčový výsledek čínského předsednictví. Principy podle jeho názoru přispějí k větší koherenci při vyjednávání dohod a budou mít dopad i nad rámec G20. ${ }^{47}$ Naneštěstí dokument nenaznačuje žádné navazující kroky a bylo by tak

40 Concluding of Report of the Heiligendamm Process, 9. 7. 2009, odst. 14.

41 Prohlášení např. vyzývá vlády k dodržování otevřeného, transparentního a nediskriminačního investičního klimatu. Současně potvrzuje, že státy se mohou zavázat k dodržování vysoké úrovně investiční ochrany i při zachování práva na regulaci ve veřejném zájmu. Zdůrazňuje také, že vlády by neměly snižovat standardy za účelem zvyšování atraktivity pro zahraniční investory.

42 APEC Non-Binding Investment Principles (2011 Update), 2011/AMM/014app04, 23rd APEC Ministerial Meeting, 11. 11.2011.

43 BJORKLUND, A. K.: Assessing the effectiveness of soft law instruments in international law. In BJORKLUND, A. K. - REINISCH, A.: International Investment Law and Soft Law, Cheltenham, 2012, S. 60-61.

44 SAUVANT, c. d., s. 83.

45 BERGER, A.: A Multilateral Investment Agreement: A Road to Nowhere? In G20 Hangzhou Summit 2016: Proposals for Trade, Investment, ad Sustainable Development Outcomes, International Centre for Trade and Sustainable Development, 2016, s. 65; LIN, J. Y. China's G20 Agenda: Call for a Multilateral Investment Framework for Development. In G20 Hangzhou Summit 2016: Proposals for Trade, Investment, ad Sustainable Development Outcomes, International Centre for Trade and Sustainable Development, 2016, s. 57-58.

46 NOVIK, A.: G20 serves an appetiser to a potential investment policy feast. In OECD Insights Blog [online]. 15. 11. 2016. Dostupné na <http://oecdinsights.org/2016/07/13/g20-serves-an-appetiser-to-apotential-investment-policy-feast/>.

47 MUKHISA, K.: G20 Trade Ministers Meeting. Statement by Mr. Mukhisa Kituyi, SecretaryGeneral of UNCTAD. In UNCTAD [online]. 15. 11. 2016. Dostupné na $<\mathrm{http}$ //unctad.org/en/pages /SGStatementDetails.aspx? OriginalVersionID $=215>$. 
poměrně optimistické interpretovat Principy jako významný posun k vytvoření jednotného investičního režimu.

Principy mají navíc svá negativa. Především se vyznačují značnou neurčitostí. To není u soft law dokumentů, snažících se o co nejširší mezinárodní přijetí, výjimečné. Pokud je však obsah dokumentu hodně obecný, je jeho přidaná hodnota pro tvůrce investičních politik stejně jako pro vyjednavače investičních dohod omezená. Na druhou stranu mohla být snaha zahrnout některé další zásady, nebo jejich přesnější vymezení, kontraproduktivní. V takovém př́padě jsou strany méně ochotné ke kompromisu, protože prokázaná ochota ustoupit ve vybraných oblastech by mohla oslabit jejich pozice v probíhajících nebo perspektivních vyjednáváních o úpravě investic. Rovněž ale vynechání některých principů je možné interpretovat jako ztrátu jejich významu, proti čemuž se některé země mohou zdráhat. ${ }^{48}$ Lze tedy připustit, že dosažení smysluplného textu i v př́ípadě obecných nezávazných Principů nemuselo být jednoduché a obtíže spojené s nalezením kompromisního textu během krátké doby od založení pracovní skupiny do př́pravy setkání ministrů G20 pro obchod není patřičné podceňovat.

Panuje zde však nejistota i v samotném rozsahu působnosti Principů. Zaprvé není jasné, zda se vztahují pouze na investice soukromé, nebo také v rámci veřejného sektoru. Druhou závažnou nevyjasněnou otázkou je, zda se dokument vztahuje na všechny formy investic, nebo pouze zahraniční. V dokumentu se sice jednou zmiňují zahraniční investice, nicméně ve zbytku textu se používá obecného označení investice. To má vážné dopady na praktické uplatnění Principů, pokud by se vztahovaly také na domácí investice. Principy samotné se pak vyznačují také řadou obecných pojmů, kdy např. není jasné, co přesně je myšleno protekcionismem v kontextu prvního principu. Oproti tomu právo státu na regulaci ve veřejném legitimním zájmu je stanoveno v šestém principu jasně a bez pochybností. Tyto kontrasty zrovna nevypovídají o správně nastavené rovnováze mezi právy a povinnostmi vyplývajícími z Principů pro členy G20. ${ }^{49}$ Zcela pak chybí některé důležité aspekty současné veřejné i odborné debaty o stavu mezinárodního investičního práva jako uznání, že současný systém lze reformovat, nebo určení cílů investičních dohod.

\section{ZÁVĚR}

Skupina G20 původně vznikla za účelem řešení hospodářských a finančních potíží spojených s globální krizí. Její role krizového managementu se ale postupně mění. Skupina získává pevnější strukturu a má ambici se stát význačným fórem i pro spolupráci v oblasti obchodu a investic. Významným krokem v tomto směru je bezpochyby založení pracovní skupiny pro obchod a investice během čínského předsednictví $\mathrm{v}$ uplynulém roce, což vytvořilo vhodné podmínky pro zařazení otázek spojených s úpravou investic v agendě G20. Spolu se stanovením mandátu pracovní skupiny získala G20 platformu, která umožní členským státům definovat další směřování, a tak účinněji pří-

48 SAUVANT, c. d., s. 83.

49 EVENETT, S. J. - FRITZ, J.: FDI Recovers? The 20th Global Trade Alert Report. Centre for Economic Policy Research, 2016, s. 30. 
stupovat $\mathrm{k}$ výzvám, kterým obchodní a investiční systém čelí. G20 jako diskuzní fórum může být navíc efektivnější v těchto snahách i v porovnání s tradičními mezinárodními organizacemi jako OSN nebo WTO, kde je historická dělící linie Sever-Jih patrnější.

Oživenému zájmu o nastavení multilaterálních investičních pravidel nahrávají změny v mezinárodních investičních tocích. Oproti dřívějšku narůstá podíl přímých zahraničních investic z rozvojových zemí. V důsledku toho se mění také jejich národní zájmy při prosazování investičních pravidel, což může otevřít cestu širšímu konsenzu $\mathrm{s}$ vyspělými zeměmi, které se naopak pomalu snaží o vyrovnanějši přístup $\mathrm{k}$ ochraně investic. Nejvýrazněji se tento posun v investičních tocích projevuje v př́padě Číny, která se v roce 2013 stala třetím největším vývozcem kapitálu a v dohledné době se pravděpodobně stane vůbec největším zdrojem přímých zahraničních investic. Čína je také vhodným př́kladem toho, jak rozvojové země projevují větší zájem o nastavení mezinárodních pravidel pro investice, než tomu bývalo $\mathrm{v}$ minulosti. Její aktivita $\mathrm{v}$ této oblasti v rámci předsednictví G20 byla mimořádná a ve výsledku přinesla i konkrétní výstup v podobě Principů pro tvorbu globálních investičních politik. Ačkoliv se jedná o obecný a na mnoha místech nejednoznačný dokument, je možné jej považovat za slibný začátek aktivit G20. Bude však hodně záležet na dalších předsednických zemí, jak vysoko zařadí investice mezi své priority. $V$ rámci programových priorit německého předsednictví $\mathrm{v}$ tomto roce jsou investice uvedeny poměrně obecně a především $\mathrm{v}$ souvislosti s usnadňováním investic. ${ }^{50}$ Lze proto předpokládat, že investiční agenda během roku 2017 alespoň částečně ztratí na pozornosti, které se jí dostávalo.

Dosažení širší shody nad společným př́stupem v oblasti zahraničních investic se ukázalo v minulosti nesnadným cílem a v podstatě podobné snahy vždy skončily neúspěchem kvůli rozdílným zájmům zemí, které investice vyvážejí a přijímají, a businessu a veřejnosti. I dnes jsme svědky toho, jak jsou nástroje investiční ochrany ve formě BITs nebo FTAs předmětem vášnivých debat a vyvolávají u veřejnosti i politické reprezentace značné obavy. Principy G20 se zjevně snaží docílit rovnováhy a zohlednit jak zájmy rozvojových, tak rozvinutých zemí a současně najít střední cestu mezi ochranou a podporou na straně jedné a právem vlád na regulaci na straně druhé. Musíme je také chápat v kontextu citovaných deklarací představitelů G20 - jako nástroj pro oživení hospodářského růstu, posílení toků přeshraničních investic či zajištění alespoň určité úrovně koherentního investičního prostředí. Bylo by předčasné Principy hodnotit jako začátek diskuzí o multilaterální investiční dohodě. Přestože zaznívají hlasy o vhodných podmínkách pro oživení prací na takové dohodě, ${ }^{51}$ podobné volání zaznělo v minulosti již několikrát. Principy však mohou sehrát svoji pozitivní roli a ukázat se přiměřeným předpokladem pro sjednocování mezinárodních standardů pro zahraniční investice a první vlaštovkou G20 jako nového fóra v této oblasti.

Mgr. Bc. Ondřej Svoboda

Univerzita Karlova, Právnická fakulta; Ministerstvo průmyslu a obchodu ČR ondrej.svobod@gmail.com

50 G20 Germany 2017. Priorities of the 2017 G20 Summit, 1. 12. 2016, s. 6-7.

51 Např. LIN, c. d., s. 58. 